\title{
Partnership Dynamics among Immigrants and Their Descendants in Four European Countries
}

\author{
Tina Hannemann, University of Manchester, UK \\ Hill Kulu, University of St Andrews, UK \\ Amparo González-Ferrer, CSIC, Spain \\ Ariane Pailhé, INED, France \\ Leen Rahnu, Tallinn University, Estonia \\ Allan Puur, Tallinn University, Estonia
}

Acknowledgements:

The research leading to these results has received funding from the European Union's Seventh Framework Programme (FP7/2007-2013) under grant agreement no. 320116 for the research project FamiliesAndSocieties. For Leen Rahnu and Allan Puur this work was also supported by the Estonian Research Council grant (PRG71). Hill Kulu's work was also supported by Economic and Social Research Council grant ES/K007394/1 and carried out in the ESRC Centre for Population Change (CPC). We also express our gratitude to Gunnar Andersson, Laura Bernardi and the reviewers for valuable comments and suggestions on previous versions of this article. 


\title{
Partnership Dynamics among Immigrants and Their Descendants in Four European Countries
}

\begin{abstract}
:
This study investigates union formation and dissolution among immigrants and their descendants in four European countries with different migration histories and family patterns (United Kingdom, France, Spain and Estonia). Although there is a growing body of literature on migrant families in Europe, there is still little comparative research on partnership dynamics among immigrants and their descendants. We apply event history analysis to pooled data from the four countries. The analysis shows a significant variation in partnership patterns across migrant groups in some countries (e.g., South Asians versus Caribbeans in the UK) and similar partnership behaviour for some migrant groups in different countries (e.g., South Asians in the UK and immigrants from Turkey in France). Descendants of immigrants often exhibit partnership patterns that are similar to those of their parents' generation. The country context matters; specific patterns are observed for Spain and Estonia.
\end{abstract}

Keywords: Family, marriage, cohabitation, divorce, immigrants, the second generation, Europe, Poisson regression 


\section{Introduction}

Over the past decades, many European societies have experienced large-scale immigration flows and the growing ethnic and cultural heterogeneity of their populations (Castles and Miller 2009). The recent demographic literature has shown an increasing interest in the study of family dynamics and patterns among immigrants and their descendants. One research strand investigates the formation, location and stability of ethnically mixed marriages including research on union formation in Europe across borders (Dribe and Lundh 2012; González-Ferrer 2006; Kalmijn and Van Tubergen 2006; Milewski and Kulu 2014). Another strand examines fertility patterns among immigrants and ethnic minorities (Andersson 2004; Goldscheider et al. 2011; Kulu et al. 2017; Kulu and Milewski 2007; Milewski 2007; Toulemon 2004). Although previous research has significantly improved our understanding of family patterns of immigrants and their descendants in European countries, most studies have investigated immigrants in one or two countries. Gradually emerging comparative research demonstrates how the analysis of immigrants and ethnic minorities from several different countries significantly advances our understanding of how institutional and policy provisions shape the family lives of immigrants and their descendants (Huschek et al. 2012; Kulu et al. 2017; Milewski 2011).

This study investigates union formation and dissolution among immigrants and their descendants in the UK, France, Spain and Estonia. The objective of this study is to compare partnership patterns of immigrants, their descendants and natives and to identify commonalities and differences among those migrant groups across the four selected countries. The study builds on the literature on immigrant family and fertility and extends previous research in the following ways. First, the study investigates partnership patterns among individuals with immigrant family background from a comparative perspective. Although recent studies have investigated partnership patterns among immigrants (Andersson et al. 2015; González-Ferrer et al. 2016; Hannemann and Kulu 2015; Pailhé 2015), only a few studies have compared immigrant union formation and dissolution across European countries (Huschek et al. 2010). In this study, the population subgroups from different countries will be included in the same analysis, which allows a direct comparison of the partnership patterns of the various native and immigrant groups. The studied countries represent the 'old' immigration countries of Northern and Western Europe (the UK and France); the 'new' immigration countries of Southern Europe (Spain); and Eastern European countries with migration patterns driven by specific post-WWII 
political and economic circumstances (Estonia). The countries also represent the diversity of partnership patterns and changes in the European context; included are countries with relatively early spread of cohabitation, separation and re-partnering (France and Estonia), those which followed these patterns with a time lag (UK) and those where new partnership forms emerged more recently and have developed with a slower pace (Spain). Clearly, the four countries provide a representative cross-section of the major regions of Europe and a broad variety of societal and demographic regimes.

Second, this study will contribute to the research field by simultaneously investigating various partnership transitions among immigrants and their descendants. This paper moves beyond the 'one-life-event-at-a-time' approach and will provide a better understanding of the formation and dissolution of first unions among immigrants and their descendants in these four European countries. The study will investigate the type of first partnership (cohabitation or direct marriage) and the likelihood of experiencing (first) divorce for first time married people. Although there is a growing literature on the determinants of mixed marriages (De Valk and Díez Medrano 2014; Dribe and Lundh 2012; Hannemann et al. 2018) little (if any) comparative research has been conducted on partnership formation and dissolution of immigrants and their descendants in comparison to the native population. Further, some immigrants have high levels of exogamous marriages (e.g. Southern Europeans in Western Europe), whereas endogamous marriages dominate among others (e.g. South Asians in Britain); the overall levels of union formation and dissolution in both groups are of much interest (Kleinepier and de Valk 2016). The study will thus provide us with a more holistic picture than a conventional analysis of only a single union event (usually first marriage) or determinants of exogamous/endogamous marriages.

Finally, this study will extend the scope of the topic by examining the union patterns among the descendants of immigrants, whose shares have significantly increased during the last decades (Sobotka 2008). Although the so-called 'second generation' has grown up in the host society, they have faced a number of challenges. Their educational qualifications often (although not always) remain below those of the majority population, and their labour market performance and social mobility stays below the levels of their native peers (Aeberhardt et al. 2010; Alba 2005; Aparicio 2007; Brinbaum and Cebolla-Boado 2007; Fassmann 1997; Fibbi et al. 2007; Kristen et al. 2008; Meurs et al. 2006; Van Niekerk 2007). Insufficient education and poor employment prospect (Aeberhardt et al. 2010; Alba 2005; Aparicio 2007; Brinbaum and 
Cebolla-Boado 2007; Fassmann 1997; Fibbi et al. 2007; Kristen et al. 2008; Meurs et al. 2006; Van Niekerk 2007) may have an impact on union formation and dissolution patterns among the descendants of immigrants. Our comparative study will, thus, provide valuable information on the demographic behaviour of important population subgroups in Europe and will improve our understanding of how various factors (being descendants of the post-war 'labour migrants'; institutional and policy settings of countries) have shaped partnership behaviour of the 'second generation'.

As the focus of this study is on partnership patterns among immigrants and their descendants, we will provide a brief overview of both post-war migration to Europe and of changes in partnership dynamics.

\section{The European context: migration and partnership dynamics}

\subsection{Migration}

In the second half of the 20th century, many European countries experienced economic and policy-driven migration (Castles and Miller 2009; Coleman 2006). The economic boom of the 1950s and 1960s in Western and Northern Europe attracted a large number of labour migrants. Several countries actively recruited migrants; this was driven by the increasing demand of workers in labour intensive sectors of industry and services (Salt and Clout 1976; Seifert 1997). France, West Germany, and the Netherlands, having coped with the reconstruction of their industry and infrastructure, searched for a labour force to satisfy the needs of the economic boom. The labour migrants originated mainly from Southern Europe and regions that were adjacent to Europe (e.g. Turkey). Southern European countries, including Italy, Spain and Greece, willingly sent labour migrants, partially to ease the pressure of unemployment and large cohorts that were due to high pre-war fertility levels. While early labour migrants were mainly young, single, short-term employed, educated and male, the later labour streams shifted towards being rural and unskilled, with individuals having a wide age range and including both sexes (Salt and Clout 1976).

The country of origin for labour migrants varied across the continent, which reflected the economic, demographic and also historical circumstances. France received large numbers of immigrants from their former colonies in the Maghreb region, the Netherlands received 
migrants from Indonesia and Surinam and the UK provided free immigration for individuals from India, Pakistan and the Caribbean region (Peach 1998; Serow et al. 1990). Migration from former colonies increased at the time of and after the declaration of independence in the respective countries. Political and crisis driven migration waves also occurred in Spain in the 1960s, mainly from former colonies in South America. Those migration streams that were based on historic connections and dependencies had a longer tradition than the new waves of labour migrants in the rest of Europe. Additionally, both migration streams co-existed and were partially independent of each other (Serow et al. 1990).

Patterns of international migration from the former communist countries of Eastern Europe differed from the rest of Europe in several aspects (Frejka 1996). Emigration to the West was (almost) prohibited to the citizens of Eastern European countries, with a few exceptions (e.g., Yugoslavia). Interestingly, however, 'labour migration' that was driven by the needs of centrally planned economies also existed within the Eastern Block. People from Vietnam, Angola and Mozambique moved to Central European countries, particularly to Eastern Germany, whereas Russians, Ukrainians and Belarusians moved in large numbers to the Baltic states (particularly Estonia and Latvia), which were annexed by the Soviet Union during WWII and experienced accelerated industrialisation during the post-war period (Kulu 2003). Since the fall of communism, East-West migration has significantly increased, both for economic reasons and for factors that are related to ethnic and linguistic connections (Fassmann and Münz 1994).

In the 1990s, Southern European countries also became destinations of international migration. Greece, Italy and particularly Spain, especially during the first half of the 2000s, received large numbers of immigrants from North Africa, South East Europe and South America over the past two decades. While economic and demographic factors were important factors behind those migration streams, historical and linguistic ties also played an important role (Cebolla-Boado and González-Ferrer 2008, 2013).

\subsection{Union formation and dissolution in Europe}

A shift towards earlier family formation and the prevalence of marital unions characterised much of Europe in the 1950s (Lesthaeghe and Neels 2002). New trends, including the postponement of marriages, increasing levels of divorce and remarriage and the rise of nonmarital unions, were observed since the late 1960s. These new features in partnership dynamics, 
especially the increase in cohabitations, showed significant geographical variation in their onset and magnitude. The Nordic countries, particularly Sweden, were the forerunners of these diversified family forms, while the Central and West European countries, such as France, Switzerland and Germany, followed these patterns with a time lag (Andersson and Philipov 2002; Sobotka and Toulemon 2008). Britain, despite its 'Northern' location, adopted the new patterns of union formation relatively late. However, the spread of new family forms was rapid over the past two decades, especially the rise of cohabitation and the increasing rates of divorce (Beaujouan and Ní Bhrolcháin 2011; Berrington and Diamond 2000; Ermisch and Francesconi 2000; Murphy 2000).

In Southern Europe, the new family forms emerged only recently. For a long time, marriage was the only socially accepted form of partnership; however, marriage was increasingly postponed, and the age of first marriage increased beyond that of the Northern and Western European countries. A few research studies show that the importance of religion largely explains specific partnership patterns, whereas other studies suggest that economic factors and traditional family arrangements may have played a role (Reher 1998). The patterns in Eastern Europe are diverse due to both the experience of socialism and the 'North-South' dimension. While younger marriage ages and relatively high divorce levels were common in most Eastern European countries in the 1970s and 1980s, the spread of new family forms significantly varied across countries (Hoem et al. 2010; Puur et al. 2012). A few countries closely followed partnership formation and dissolution dynamics in Nordic countries (e.g., Estonia and Latvia), whereas trends in other Eastern European countries were similar to those in Southern European countries (e.g., Poland).

Although the postponement of marriages and especially the spread of cohabitation and divorce differ across European countries, the direction of trends is shared by many countries. Figure 1 shows the risk of cohabitation (dashed lines) and direct marriage (solid lines) in the four countries analysed in this study by cohort (for native population only). The reference point is the risk of direct marriage among natives in the UK for the birth cohort of 1950-59; the union formation levels for all other groups (countries and cohorts) are measured relative to that baseline. The direct marriage rates for the UK women provide one reference point for all groups, nothing more. The main idea of such analysis strategy is that all groups and countries can be easily compared to each other (for more formal significance testing one could just change the reference point according to the needs). We observe an increase in cohabitation risks in all 
countries, with Estonia showing the highest cohabitation levels and Spain exhibiting the lowest levels, with an increase across all birth cohort groups. The trends for direct marriage are more similar across countries, with the highest levels being displayed for the oldest cohorts and the lowest risk being shown for the youngest cohorts, as expected. Unlike for cohabitation, the levels of direct marriage exhibit a noticeable convergence across countries for women born in the 1970s-1980s. The analysis thus shows strong cohort effects and it is therefore critical to include birth cohort in the analysis of partnership trends among immigrants and their descendants across countries to avoid a bias in the results.

(Figure 1 about here)

\subsection{Explaining family behaviour among immigrants and ethnic minorities}

International migration, within and across the borders of Europe, combines populations, which have different partnership formation and dissolution patterns. There are several approaches to explaining the possible differences in family behaviour between immigrants and the native population. Two of the most established approaches - socialisation and the adaptation hypothesis - include contrasting explanations for family behaviour among migrants (Andersson et al. 2015; González-Ferrer et al. 2016; Hannemann and Kulu 2015; Pailhé 2015; Rahnu et al. 2015). The socialisation hypothesis argues that migrants will follow the family traditions and values that were dominant in their childhood and, therefore, in their country of origin (Andersson 2004; Kulu and Milewski 2007). Family patterns of immigrants may also be shaped by legal and social rights, such as legal marriage age or the right to live with a non-marital partner. If partnership patterns in the home and host country vary significantly, those differences might also emerge in a comparison between immigrants and the native population. Even if social norms and legal restrictions on couples divert greatly from the home country, preferences for specific family forms might remain stable. The adaptation hypothesis, in contrast, states that over time, migrants will adapt to the family patterns that are dominant in the host country (Andersson and Scott 2005; Hervitz 1985). This naturally will differ for immigrants who spend many years in the host country and new arrivals as well as the age at migration and therefore the time they spend under the influence of the home country environment. The hypothesis can be extended to adaptation to different economic and legal aspects around marriage, cohabitation and divorce, if the circumstances vary between home and host country. This study analysis all immigrants, independent of if their first union started and 
ended before or after migrating and does not take into account time since migration. Therefore, this study will not be able to explicitly determine the impact of the adaptation hypothesis.

A competing hypothesis to the above-discussed two is the selection hypothesis (Hoem 1975; Macisco et al. 1970), which argues that individuals who leave their home country are a select population group in their home country. For example, labour migration favours specific skills and professions, which can be useful for the economy of the host countries. Good health is also necessary in order to migrate over long distances and adapt to new environments. The family behaviour of migrants thus does not necessarily represent the dominant family patterns in their home country. Differences in family behaviour between immigrants and the native population can, therefore, be the result of individual characteristics rather than the result of the context of early socialisation (Cortina Trilla et al. 2008). ${ }^{1}$ In order to measure the impact of selection among the migrant groups an analysis has to take into account the trends and changes in union formation and dissolution in all of the countries of origin as well and observe their trends parallel to those in the country of destination. Although this approach would go beyond the scope of this study, the selection hypothesis will nevertheless help to interpret results.

All three hypotheses have been successfully used in various studies to explain the presence or absence of differences in partnership patterns between immigrants and natives in European countries (Andersson et al. 2015; González-Ferrer et al. 2016; Hannemann and Kulu 2015; Pailhé 2015; Rahnu et al. 2015). Recent research has also included the descendants of post-war immigrants, the so-called 'second generation', whose share has increased substantially in many European countries (Hernandez et al. 2009; Sobotka 2008). The analysis of partnership patterns of the descendants of immigrants offers a new perspective when explaining the family dynamics among individuals with immigrant family background. If the descendants of immigrants mostly grew up under the influences of the mainstream society (socialisation by the native population) one would observe similar trends for the second generation and the natives. In contrast, the family behaviour of the descendants of immigrants would be similar to that of their parents if they grew up under the influences of the minority subculture (socialisation by the minority group). If the impact of both, the host society and the minority community is important, the

\footnotetext{
${ }^{1}$ An additional approach to explain differences in partnership patterns between immigrants and natives is the disruption hypothesis. It considers the act of immigration as an interruption for partnership trajectories among immigrants and proclaims that return to the initial union trajectories occurs with a time lag after migration (Carlson 1985; Kulu 2006). Testing the disruption hypothesis would require a detailed analysis of the timing of union formation relative to migration, which goes beyond the scope of this comparative study.
} 
descendants of immigrants would exhibit family formation patterns that are in-between those of immigrants (their parents) and the natives (their peers) (Zorlu and Mulder 2011).

Recent research investigated differences in partnership behaviour between immigrants, their descendants and the native population in different European countries, discussing as well country-specific factors. There are two main reasons why the differences between immigrants and natives may vary across countries. First, the origin and composition of immigration streams is important. Immigrants may come from countries that share similar linguistic and cultural patterns or, alternatively, those from countries exhibiting very different patterns. For example, post-war immigrants from Southern European countries are more likely to exhibit family patterns that are similar to natives in Western and Northern European countries than those who arrived from Turkey or Northern Africa (Dribe and Lundh 2012). Even the family behaviour of immigrants from the same country is likely to significantly differ based on their origin or language (e.g., Turkish versus Kurdish migrants from Turkey) or whether or not individuals have mostly moved for employment related reasons or as refugees (e.g., immigrants from the former Yugoslavian republic) (Andersson et al. 2015). The differences between immigrant groups and natives are also dynamic and prone to changes over time. Crul and Vermeulen (2003) found that, after arrival, the Turkish migrant group has benefitted from a closed community in several European countries; however, they start to fall behind in educational achievements over time, which is related to the restrictive migration policies and selective education system of the country of destination.

Second, contextual factors may account for the differences across countries. Each country will provide a set of normative expectations and legal rights and responsibilities for individuals in partnerships (marriage and cohabitation) and for separation (divorce) (Perelli-Harris and Gassen 2012). Newcomers (must) accept those as a 'baseline level' in the host country, and any adaptation to the mainstream society suggests a convergence towards this baseline. For example, immigrants in Northern Europe are more likely to cohabit prior to marriage or separate from unsatisfactorily partnerships than those who live in Southern Europe. Various state policies may be factors that largely (but not only) explain whether or not and how much convergence toward the baseline will take place among immigrants and their descendants. The adaptation process to the dominant behavioural patterns is assumed to be faster and stronger in countries with inclusive integration policies and/or with a wide range of policies that reduce differences between population subgroups and promote equality in all spheres of society than 
in countries with exclusionist integration policies (e.g., the ius soli versus ius sanguinis approach to citizenship) or where economic market forces are expected to dominate people's lives (e.g., social democratic versus liberal welfare states) (Esping-Andersen 1990; Seifert 1997).

This study investigates first union formation and dissolution in four European countries: the UK, France, Spain and Estonia. These countries represent both 'old' (UK and France), 'new' (Spain) and special circumstances (Estonia) immigration patterns; they differ in post-WWII political and economic histories. The countries that are included in the study represent some of the major regions of Europe and, hence, a broad variety of societal and demographic regimes. The diversity of the four countries offers favourable opportunities to explain the variation in family behaviour between migrant groups, as well as across the contexts of the receiving countries.

Any study on migration and migrants faces an issue of how to deal with heterogeneity. Ideally, to detect contextual effects we should compare individuals from the same origin country and with similar reasons for migrating in different destination countries. However, this is often not possible. To overcome the issue this study will compare immigrants and their descendants of similar backgrounds in different countries, e.g. labour migrants from low income countries with 'conservative' family forms and their descendants. South Asians in the UK and those from Turkey and North Africa in France are comparable groups; similarly, Caribbeans in the UK and Sub-Saharan Africans in France share similar backgrounds; they come from low-income countries where 'fluid' family forms dominate. We also emphasise the importance of comparing different groups in the same country to detect contextual effects. Our comparisons may show large differences across immigrant and minority groups in some countries, whereas differences may be small in other countries. Briefly, heterogeneity is a challenge in migrant family research, but we are confident that the proposed approach will improve our understanding of how country context influence partnership behaviour of immigrants and their descendants.

\section{Hypotheses}

Based on previous research our hypotheses are as follows. First, we expect to find a significant variation in partnership patterns among immigrants. Immigrants from countries with 'more 
conservative' family trajectories, e.g. from South Asia, Turkey or Northern Africa, are expected to show high marriage and low cohabitation and divorce levels, whereas those coming from other European countries are likely to exhibit family patterns that are similar to those of natives. We thus expect factors related to socialisation environment to shape partnership patterns among immigrants, although country context (or some adaptation) is also expected to matter for immigrants. Second, for the descendants of immigrants, we expect to find partnership patterns that fall in-between the respective immigrant group and native population. The key question is whether their partnership behaviour resembles more those of their parents or those of natives. Furthermore, the study examines how much educational differences potentially explain differences across the population subgroups. Finally, we also expect country context to matter; partnership patterns among immigrants and their descendants are expected to be more 'conservative' in Spain and more 'fluid' in Estonia, with the UK and France falling in-between.

\section{Data and methods}

\subsection{Data}

The data for this study come from national surveys of the four countries (The UK, France, Estonia and Spain). Preceding country-case studies on the topic of partnership patterns among migrant groups has shown high quality and comparability of the data (González-Ferrer et al. 2016; Hannemann and Kulu 2015; Pailhé 2015; Rahnu et al. 2015). Therefore, those four countries were chosen for the country comparative approach of this study. Aggregated samples were first prepared by each country's team and then merged into one common database for analysis.

British data come from the Understanding Society study (University of Essex et al. 2014). This analysis uses information from the first wave (2009/2011) including partnership histories (Hannemann and Kulu 2015). Data for Estonia were retrieved from the Estonian Generations and Gender Survey (2004/2005) and the Estonian Family and Fertility Survey (1994). These surveys cover the partnership histories of individuals, as well as their demographic and socioeconomic characteristics (Rahnu et al. 2015). Data for French natives and immigrants were collected from the Trajectories and Origins Survey (2008), a joint project of the French National Institute of Demography (INED) and the French National Statistical Office (INSEE). Records include full partnership histories as well as information of migrant background of individuals 
and their parents (Pailhé 2015). For Spain, the study uses data from the Fertility and Values Survey that was conducted by the Centre for Sociological Research (2006) (González-Ferrer et al. 2016).

This study focuses on the partnership trajectories of women with the focus on first union formation and dissolution among immigrants and their descendants. Each country provided data on their respective natives and immigrant groups that were specific to their country. Given the variety of migration histories, this resulted in a total of 26 migrant groups, including respective natives, immigrants (foreign-born individuals) and their descendants, the so-called second generation. Immigrants are defined as individuals born abroad. This includes individuals who started their first union in the country of origin and those who started their first union in the host country after migration. Rather than analysing only immigrants who arrived as singles, this study compares the family pattern of the descendants of migrants with all migrants, i.e. those who formed a union prior to a move from one country to another and those who partnered following the migration. Such an approach has both pros and cons. One strength is the opportunity to compare full partnership histories of immigrants with those of their descendants, which is one of the main objectives of this study. The weakness is that specific hypotheses (e.g. the adaptation hypothesis) cannot be explicitly tested for immigrants. However, as the empirical analysis will later show, in our view, the strengths outweigh the weaknesses.

An individual is classified as the descendant of immigrants if at least one parent was born abroad. In case an individual has parents with different countries of birth the priority was given to the father's origin. Given the small numbers and variety across nationalities of parents this study could not separately analyse specific groups of mixed ethnic parents. For similar reasons, there is no separate group for migrants who arrived at young ages to the destination country, although their behaviour falls often between those migrants who entered at adult ages and the second generation of migrants.

There are four immigrant groups for the UK: the first group is composed of individuals from Europe and other industrialised / Western countries (the U.S., Canada, Australia, and New Zealand; further referred to as Europe \& West). The second group consists of individuals from India, Pakistan and Bangladesh (further referred to as South Asia). Immigrants and their descendants from Caribbean countries, mainly Jamaica, are the third group; individuals from all other countries form the fourth group. For Estonia, this study investigates the partnership 
dynamics of natives and immigrants who are mainly from the Slavic republics of the former Soviet Union (Russia, Belorussia and Ukraine; further referred to as Russian-speaking population) and their descendants, which form approximately $90 \%$ of minorities in Estonia.

For France, with its long history of immigration, data on four immigration origins are analysed: individuals from former colonies and territories: Maghreb states and Sub-Saharan African countries (further referred to as Africa); and more recent countries of origin: Turkey and Southern European countries. Immigrants and their descendants are distinguished for all four groups; this is possible because the descendants of those immigrant groups have already reached the age of partnership formation and dissolution. For Spain, in contrast, it is only possible to investigate partnership dynamics among immigrants. The country has only recently experienced large immigration streams; therefore, the number of descendants of immigrants who have reached the age of partnership formation is still small. The analysis distinguishes between immigrants from Eastern Europe, Latin America, the EU-15 countries and all other countries.

\subsection{Methods}

For a comparative study of $n$ countries regarding partnership formation and dissolution, an option is to merge individual-level data from the countries and then fit a hazard regression model (Hoem et al. 2010). However, this is often not possible due to the issues of data confidentiality: individual-level data cannot be released to another country or research group to conduct a comparative analysis. Fortunately, it is possible to overcome this obstacle by using the count-data approach to compare partnership formation and dissolution rates across countries and population subgroups. Researchers need to prepare an event-time (or occurrence-exposure) table for each country, which is defined by a cross-classification over a set of time intervals and covariate categories (Hoem 1987; Preston 2005; Kulu et al. 2017). The data for each cell in such a table include the total number of events, $E_{j k}$; the total time (e.g. person-years or personmonths) at risk, $R_{j k}$; and values of covariates, $x_{j k}$, for time period $j$ and category $k$. For each cell, the ratio of the number of events to the risk-time is a crude hazard:

$$
\lambda_{j k}=E_{j k} / R_{j k}
$$


where $\lambda_{j k}$ is the hazard for category $k$ in time period $j$. Let $E_{j k}$ denote the number of first union formations for group $k$ in age group $j$. We treat $E_{j k}$ as the realisation of a Poisson random variable with the mean $\mu_{j k}$ :

$$
\mu_{j k}=\lambda_{j k} \times R_{j k}
$$

The expected number of first unions is, thus, the product of the hazard of first union formation and exposure time. We can present this model in a log-linear format:

$$
\ln \mu_{j k}=\ln \lambda_{j k}+\ln R_{j k}
$$

We then rearrange the equation to investigate the hazard of first union formation:

$$
\ln \left(\mu_{j k} / R_{j k}\right)=\ln \lambda_{j k}
$$

Finally, we present a log-linear model for the hazard of first union formation, which also includes (additional) covariates:

$$
\ln \lambda_{j k}=\alpha_{j}+x_{k}^{\prime} \beta
$$

where $\alpha_{j}=\ln \lambda_{j}$ measures the hazard of first union formation by age (the 'baseline'), $\mathbf{x}^{\prime}{ }_{k}$ is a vector of the covariates (e.g., ethnic background, educational level and birth cohort) and $\boldsymbol{\beta}$ represents a vector of the parameters to measure their effects.

In this paper, we analyse partnership formation and dissolution among immigrants and their descendants in four European countries (the UK, Estonia, France and Spain) (Figure 2). For partnership formation, an individual becomes under risk at age 16, independently if the individual is a native, an immigrant or a descendant of immigrants and will be censored at age 45 or the last interview date, whichever comes first. For partnership dissolution this study analyses divorce from marriage in the first union. All women who married in their first union, independent of whether they cohabited prior to marriage or not, form the risk population for divorce. Women are at risk from the beginning of the relationship, this includes the period of living together in cohabitation if they did not marry directly. Often divorce risk is measured 
from the date of the wedding, however, this study is interested in the overall partnership duration which can vary largely if marriage was preceded by a lengthy period of cohabitation. Again, the approach has both pros and cons. One strength is that cohabitation and a subsequent marriage are treated as the same (rather than different) union, which is somehow natural, also in the light of recent research (Jalovaara and Kulu 2019). The weakness is that we may observe a more erratic divorce pattern over union duration (we thank a reviewer for drawing our attention to that). Nevertheless, as our focus is on the differences across migrant groups rather than on the patterns over union duration, there is not much difference between the strategies. Marriages are censored after 20 years, the death of their partner or the last interview date, whichever occurred first. For immigrants we include in the analysis both partnership transitions that occurred prior and after immigration. Previous analysis of partnership behaviour in individual countries showed no significant differences in partnership patterns among immigrants prior and after migration (Rahnu et al. 2015).

(Figure 2 about here)

The individual-level data, thus, used to calculate aggregated exposure-occurrence tables for each country, were aggregated by different combinations of socio-demographic variables; the country files were then merged into one common database and modelled by using Poisson regression models (5). The variables that were used to prepare exposure-occurrence tables were as follows: migrant group (specific to country, see description above), birth cohort (1950-59, 1960-69, 1970-79, 1980-89), age group $(16-19,20-24,25-29,30-34,35-39,40+)$ or alternatively for measuring marriage duration $(0-11,12-35,36-71,72-119,120+$ months $)$ and educational level (low, medium and high, according to ISCED (1997) levels 0-2, 3-4 and 5-6). We, thus, investigated the hazard of union formation and dissolution by migrant group when controlling for age (union formation) or union duration (divorce), cohort and educational level. Table 1 provides the number of events and person-months spent under risk for each partnership transition in the four countries, stratified by migrant group.

(Table 1 about here)

In order to compare individual migrant groups with each other, including across country boarder, this study analyses all countries and migrant groups parallel with only one reference group (Native British). This way all migrant groups are compared to the same benchmark and 
a true comparative analysis can be achieved. The sample size varies by countries and migrant groups. For that reason, all calculations were additionally conducted using weights to adjust for the sample size of each country (not shown here). However, the results of the models with weights and those without them showed no noticeable differences because the models distinguish between the different migrant groups and countries. Therefore, we will only present the results that do not include weights.

\section{Results}

\subsection{Union formation}

The first partnership event to be analysed is the transition from singlehood into a first union, including both direct marriage and cohabitation. Native British women are the reference group in all models. Table 2 shows that most migrant women have a lower risk of first union formation than native British women (or native French women), meaning they form the first partnership at later ages than native British or French women. However, the highest union formation levels are observed for migrants from South Asia to the UK, those from Turkey to France and all population groups in Estonia. There are large differences between migrant groups in their respective countries, as well as between the countries. France and the UK both show similar patterns, with certain immigrant groups exhibiting low risks of union formation and other immigrants exhibiting relatively high risks. All groups in Estonia have a high risk of union formation, with immigrants and their descendants experiencing even higher levels than Estonian native women. Additional analysis showed that the elevated risks of union formation mainly reflect the comparatively early entry into first unions that is characteristic of all groups, whereas the difference between Estonian natives and immigrants stems from the lower proportion of people who remain single within the latter group (Rahnu et al. 2015). All migrant groups in Spain show a relatively low risk of union formation. However, most immigrants in Spain have a significantly higher risk of union formation than native Spanish women. All included socio-demographic covariates show the expected coefficient signs, with the risk of union formation being highest for women in their twenties, older birth cohorts and lower educational groups.

(Table 2 about here) 


\subsection{Cohabitation or direct marriage?}

Next, the pathways of first union formation are analysed, distinguishing between cohabitations and direct marriages. While union formation rates provide information about the propensity of immigrants and their descendants to form a union in general, the levels of cohabitation and direct marriage offer insights into the choice of union type. Native British and also native French women show a higher risk of cohabitation than most other groups (Table 2, Figure 3). The highest risk of cohabitation is experienced by the Estonian population, particularly their native group. These results reflect the early onset and wide acceptance of cohabitation in Estonia; both based on the trends in Scandinavia rather than those in Eastern and Central European countries (Katus et al. 2008).

The high risk of cohabitation among native French women is in contrast with a low risk among non-European immigrants as well as their descendants in France. Migrants from Southern Europe to France and their descendants demonstrate lower risk of cohabitation than the native French women, but the cohabitation levels are higher than those among non-Europeans. In Spain, the opposite picture emerges, with Spanish native women exhibiting the lowest cohabitation levels. Although all immigrant groups in Spain have a higher risk of cohabitation than native Spanish women, their levels stay below those of the native British or native French women, as well as all groups in Estonia. Non-marital unions are still uncommon in Spain. Even after the legalisation of divorce and a decrease in marriage rates over the last decades, cohabitation has only very recently spread within the population (González-Ferrer et al. 2016). Immigrants in Spain show somewhat higher cohabitation levels and potentially promote the spread of new partnership forms among the native Spanish population.

(Figure 3 about here)

The low risk of cohabitation among certain immigrant groups and their descendants is often compensated with a high risk of direct marriage (Table 2, Figure 4). The most distinct groups are migrants from South Asia to the UK and their descendants and women of Turkish origin in France. While those four groups showed a low cohabitation risk, they exhibit a high risk of marrying directly (marriage without prior cohabitation). The observed patterns underline the conservative pathway of union formation among those minority groups. A similar although less pronounced contrast between cohabitation and direct marriage is observed for Estonia. The 
native Estonian women have a significantly higher risk of cohabiting and lower propensity of marrying directly, in comparison with immigrants and their descendants in Estonia.

(Figure 4 about here)

A distinct pattern is also observed for Caribbean migrants to the UK and their descendants. Both generations exhibit a low risk of cohabitation, although their cohabitation levels are higher than those of other non-European groups in the UK and France. Further, they also show the lowest risk of direct marriage across all migrant groups. The possible reasons for a relatively low likelihood of forming a union may be related to specific family forms in the Caribbean region where childbearing may precede marriage and 'visiting unions' are commonplace (Berrington 1994; Miner 2003). Interestingly, similar patterns of low cohabitation and low direct marriage levels, and perhaps similar explanations, are observed for Sub-Saharan African migrants to France and their descendants. Also, native French women have lower risk of direct marriage than the native British women and migrant groups in France. Finally, a relatively high risk for direct marriage is observed for migrants from the Maghreb states to France and all migrant groups in Spain.

\subsection{Divorce}

We next analysed patterns of marital separation. The risk population consists of all women who married in their first union, with or without prior cohabitation.

(Table 3 about here)

Women from South Asia in the UK and those from Turkey in France have a low divorce risk Table 3, Figure 5). Interestingly, however, for the descendants of those migrant groups we observe divorce levels, which are between those of immigrants and natives in those countries, although estimated risk levels have wide confidence intervals. The highest risk of divorce in the UK is observed for women of Caribbean origin, both immigrants and their descendants. In France, the descendants of Sub-Saharan African immigrants show elevated divorce levels, while the divorce risk is somewhat lower for immigrants. Overall, the descendants of immigrants in the UK and France seem to have higher levels of divorce than their parents' 
generation supporting the importance of the impact from the mainstream society, where divorce is more common.

In Estonia, all population subgroups have a higher risk of divorce. In Spain, natives, immigrants and their descendants have low divorce levels; the lowest being observed among the native Spanish women. Although divorce has been legal in Spain for several decades, the divorce levels are still significantly lower than in Western, Northern and Eastern European countries.

(Figure 5 about here)

\subsection{Changes across birth cohorts}

Figure 1 showed that partnership patterns have significantly changed over the last decades in European countries. To investigate changes over time by population subgroups we conducted analysis of union formation and dissolution by birth cohort (Table 4). The sample was divided into individuals born between 1950-1969 and those born in 1970 and later. Due to small numbers the descendants from the Maghreb states and Turkey in France were combined into one group. For the same reason, immigrants in Spain were aggregated into two groups (Europeans and other). Older and younger cohorts were distinguished in each of the twentythree migrant groups.

As expected, women from younger cohorts exhibit an overall trend of increased risk for cohabitation. The increase in cohabitation levels is pronounced for the native groups in the UK, France and Estonia, but not in Spain. However, the spread of cohabitation among younger cohorts is not universal among all migrant groups. Migrants from South Asia to the UK and their descendants and those from Maghreb states and Turkey in France show low cohabitation levels for both birth cohorts, which suggests that there has been little change across cohorts.

(Table 4 about here)

Differences in the trends across population subgroups are also observed for direct marriage. The largest decrease in direct marriage risk across birth cohorts is observed for the native groups, including that in Spain, which largely corresponds to the patterns reported for cohabitation (see also Figure 1). Further, the migrant groups in Estonia and Spain show a large decrease in direct marriage rates. However, for some minority groups the risk of direct marriage 
is as high or even higher among the youngest cohort. These include South Asian women in the UK and women from Turkey and the Maghreb states in France.

For divorce, we observe a sharp increase in divorce levels among some minority groups, e.g. Caribbean women in the UK and the Russian-speaking population in Estonia. Again, there is little (if any) change by birth cohort among South Asians in the UK and women of Turkish and Northern African origin in France. This is true for both immigrants and their descendants, although the descendants have higher divorce levels. The analysis of union formation and dissolution by birth cohort thus shows that while cohabitation and divorce levels have increased and marriage levels declined among native populations in all four countries, the patterns among immigrants and their descendants are diverse. For most migrant groups, we observe higher divorce risks in the second generation than in the immigrant groups. While some of them are even higher than their respective native groups, others stay below the reference group, closer to their parent's migrant group.

\section{Summary and conclusion}

This study analysed union formation and dissolution among immigrants, their descendants and native women in four European countries. Pooling data from the UK, France, Estonia and Spain allowed for a direct comparison between immigrants, their descendants and natives in the respective countries, as well as between the countries. The results highlight the following union formation and dissolution patterns for immigrants and their descendants.

First, the analysis showed a significant variation in partnership behaviour across migrant groups, in the same country. We observed high rates of (direct) marriage and low levels of cohabitation and marital dissolution for women from South Asia to the UK and low rates of marriage and high levels of cohabitation and union dissolution for Caribbean women. Similarly, contrasting patterns were found for different migrant groups in France: women from Turkey exhibited conservative partnership patterns, whereas those from Sub-Saharan Africa showed the opposite patterns. The persistence of strong differences of union formation and dissolution patterns between immigrant groups and respective native population provides support for the socialisation hypothesis, stressing the importance of the early life social environment. 
Second, immigrants from countries with 'conservative' family behaviour showed similar patterns of union formation and dissolution across countries in several cases. Turkish women in France and South Asian women in the UK exhibited similar partnership patterns. Those similarities were persistent throughout the range of partnership transitions that were analysed in this study. The results further support that socialisation plays an important role in the partnership behaviour of immigrants: immigrants normally bring their own traditions and norms regarding family life, which shape their family behaviour (Andersson 2004; Kulu and Milewski 2007). Nevertheless, certain changes in behaviour can be expected particularly based on the duration of stay in the destination country, age at immigration as well as selection processes. However, these changes can only be detected when comparing the partnership patterns for immigrants to those that are dominant in their countries of origin, an investigation which was beyond the scope of this study.

Third, we expected the descendants of immigrants to exhibit partnership patterns that were between those of their parents' generation and the respective natives in the host country, providing evidence that the socialisation process of descendants of immigrants takes place under the influence of both, the mainstream society as well as the minority subculture. However, the results show diverse relationships between generations across migrant groups. For geographically close and culturally similar immigrants and their descendants (Europeans in the UK and France) we observed relatively similar partnership patterns for immigrants, their descendants in comparison with the respective natives in their host countries. For culturally more distant groups, the relationships are more complex. South Asians and Caribbeans in the UK, women of Turkish, Sub-Saharan and Maghreb origin in France as well as the Russianspeaking population in Estonia showed very similar union patterns across generations, which were different from those of the respective native women. At the same time, however, their divorce levels were 'in-between' those of immigrants and natives. The analysis of partnership patterns by birth cohort showed changes similar to respective natives among Caribbeans in the UK and Russian-speaking women in Estonia, whereas marriage levels were high and cohabitation and divorce levels low both among older and younger cohorts of South Asians in the UK and women of Turkish and Maghreb origin in France. The results suggest the presence of minority subcultures in both countries, which significantly shape partnership behaviour of the descendants of immigrants. However, a possible additional impact factor is the presence of partnership patterns in the countries of origin. New arriving migrants from the home countries could introduce and advertise those patterns in the country of destination. This is reinforced 
when the immigrants are arriving as spouses of first- and second-generation immigrants who already settled in the country of destination. If a community rejects the host countries family patterns, importing a spouse might be a way of preserving cultural traits. While including the ethnicity of the partner for each of the investigated relationship forms in this paper goes beyond the scope, other articles have analysed this aspect of family formation in detail (González-Ferrer et al. 2018; Kulu and Hannemann 2018; Puur et al. 2018).

The critical question is, whether the specific partnership patterns are an indicator of cultural diversity or (also) of the poor economic and social integration of these migrant groups in their respective countries. On the one hand, the inclusion of educational level in the analysis did not change the observed differences by large amounts across population subgroups, suggesting that cultural and normative factors rather than education and employment-related factors may be important in explaining differences in partnership behaviour between population subgroups (Hannemann and Kulu 2015; Pailhé 2015). A recent study by Perelli-Harris and Lyons-Amos (2016) analysing the effect of education and country on partnership patterns in 14 European countries and the United States concluded that educational gradients for partnership patterns were not uniform across all countries and country-specific factors outweighed the effect of education among women in decisions about union formation and dissolution. This would suggest that economic, legal and cultural circumstances, which are specific for each country, influence partnership decisions. On the other hand, large group sizes with high levels of residential and spatial segregation have certainly supported the specific patterns that are observed for the second generation in the UK, France and in Estonia. These factors have facilitated daily social interaction between members of the same ethnic group and provided access to a pool of potential co-ethnic partners sharing similar family values. In Estonia, separate school systems and languages have further hindered interaction between majority and minority populations (Rahnu et al. 2015).

Fourth, the analysis showed that the country context matters in regard to union formation and dissolution. There was a notable similarity between the partnership patterns for immigrants in the UK and France (i.e., comparable groups that behaved similarly), which partly can be explained by cultural differences between the countries of origin and destination. Additionally, both countries have experienced similar changes in partnership dynamics over the past half century as well as demonstrated comparable approaches to migration and integration policies. Estonia and Spain showed country-specific patterns throughout the analysed partnership 
transitions. Although the partnership patterns of immigrants and their descendants were different than those of the natives in Estonia, the differences were not large when compared to patterns in other countries (or groups), except for the mode of union formation. The prevalence of non-traditional family forms is characteristic of all population subgroups in Estonia, which is partially explained by the country's communist past (early partnership formation and high divorce) and cultural proximity to Scandinavia (high levels of cohabitation and also divorce) (Katus et al. 2008).

In Spain, in contrast, both natives and immigrants exhibited relatively high direct marriage rates and low cohabitation and divorce levels. Previous research has emphasised the role of religion in explaining the specific partnership patterns in Spain (Domínguez-Folgueras and CastroMartín 2008, 2013), although economic factors (high youth unemployment) may also play a role. Under the regime of Franco, in accordance with the Catholic Church, divorce was illegal, and non-marital unions were not tolerated. Although divorce and cohabitation are legal for some time now, the spread of cohabitation and union dissolution, as observed in other European countries, is only recently gaining momentum in Spain (González-Ferrer et al. 2016). In such a scenario it is likely that changes in partnership behaviour among the native population are at least partly influenced by more fluid partnership patterns among migrant groups.

Additionally, this study analysed on changes in partnership behaviour across birth cohorts, with and without controlling for educational level and showed little (if any) change in partnership behaviour over time for immigrants from countries with 'conservative' family patterns and their descendants. Previous research suggests that often behavioural changes are first observed among the highly-educated individuals followed by others only with some time lag (Lesthaeghe and Neels 2002). If this was the case, then a detailed analysis of partnership patterns among immigrants and their descendants by education over time should provide an answer. Alternatively, changes could start among those with the lowest educational levels suggesting the critical role economic hardship in explaining partnership patterns (Perelli-Harris et al. 2010; Perelli-Harris and Gerber 2011). However, we were unable to test these issues with data at hand; a larger sample is needed for a detailed analysis of partnership behaviour by migrant groups over time. Further research should be conducted to analyse the role of education in the immigrant and minority family behaviour in more detail. This important avenue of research would deepen our understanding of the complex links between economic and social integration and the partnership patterns of immigrants and their descendants in European societies. 
In this study, we included in the analysis full partnership histories for immigrants, i.e. partnership events that happened before and after migration. The reason for that was to provide the opportunity to compare partnership behaviour of immigrants and their descendants over the life course. Although the study supported the importance of socialisation factors in shaping partnership behaviour of immigrants, our strategy did not allow the explicit testing of the adaptation hypothesis for immigrants. Ideally, we should compare partnership behaviour of people in the country of origin, that of immigrants and their descendants and of non-migrants in the host country. However, this would require similar data from many more countries than is often available. Still, there are some good examples on individual countries (e.g. Puur et al. 2017) and efforts should be made to extend such studies also to comparative settings to gain a better understanding of how changing patterns in countries of origin and destination interact with immigrants' and their descendants' family behaviour.

This study calculated union formation and dissolution rates for various population subgroups adjusted to basic sociodemographic characteristics of individuals to determine how much compositional factors account for differences across groups. This is a significant step to improve our understanding of factors shaping family behaviour of immigrants and their descendants. The challenge and opportunity for future research is to also include in comparative studies socio-cultural characteristics of individuals, e.g. the level of religiosity. This, however, will set high demands for the data availability, quality and harmonisation for comparative research. Needless to emphasise, the effect of various contextual factors on immigrant family behaviour, e.g. welfare regimes, immigration and integration policies should be explicitly measured. The application of multilevel modelling in the study of immigrant and minority family is thus another way of gaining a deeper understanding of how the context shapes partnership behaviour of immigrants and their descendants.

This study provided an in-depth analysis of the formation and dissolution of the first union for natives, immigrants and their descendants in four European countries. To our best knowledge, this is the first study to provide an explicit comparison of both partnership formation and dissolution across different migrant groups in a number of European countries. The analysis showed a significant variation in partnership patterns across immigrants and their descendants in the same country, and striking similarities for some minority groups across different 
countries, suggesting that the factors related to socialisation and minority background are important for shaping partnership behaviour of immigrants and their descendants. 


\section{References}

Aeberhardt, R., Fougere, D., Pouget, J., \& Rathelot, R. (2010). Wages and employment of French workers with African origin. Journal of Population Economics, 23(3), 881-905. doi:10.1007/s00148-009-0266-3

Alba, R. (2005). Bright vs. blurred boundaries: Second-generation assimilation and exclusion in France, Germany, and the United States. Ethnic and Racial Studies, 28(1), 20-49. doi:10.1080/0141987042000280003

Andersson, G. (2004). Childbearing after migration: Fertility patterns of foreign-born women in Sweden. International Migration Review, 38(2), 747-774. doi:10.1111/j.17477379.2004.tb00216.x

Andersson, G., Obućina, O., \& Scott, K. (2015). Marriage and divorce of immigrants and descendants of immigrants in Sweden. Demographic Research, 33(1), 31-64. doi:10.4054/DemRes.2015.33.2

Andersson, G., \& Philipov, D. (2002). Life-table representations of family dynamics in Sweden, Hungary, and 14 other FFS countries: A project of descriptions of demographic behavior. Demographic Research, 7(4), 67-144. http://www.demographicresearch.org/volumes/vol7/4/

Andersson, G., \& Scott, K. (2005). Labour-market status and first-time parenthood: The experience of immigrant women in Sweden, 1981-97. Population Studies, 59(1), 21-38. doi: $10.1080 / 0032472052000332683$

Aparicio, R. (2007). The Integration of the Second and 1.5 Generations of Moroccan, Dominican and Peruvian Origin in Madrid and Barcelona. Journal of Ethnic and Migration Studies, 33(7), 1169-1193. doi:10.1080/13691830701541713

Beaujouan, É., \& Ní Bhrolcháin, M. (2011). Cohabitation and marriage in Britain since the 1970s. Population trends, 145(Autumn Issue), 35-59.

Berrington, A. (1994). Marriage and family formation among the white and ethnic minority populations in Britain. Ethnic and Racial Studies, 17(3), 517-546.

Berrington, A., \& Diamond, I. (2000). Marriage or cohabitation: A competing risks analysis of first-partnership formation among the 1958 British Birth cohort. Journal of the Royal Statistical Society. Series A (Statistics in Society), 163(2), 127-151. doi:10.2307/2680494

Brinbaum, Y., \& Cebolla-Boado, H. (2007). The school careers of ethnic minority youth in France: Success or disillusion? Ethnicities, 7(3), 445-474. doi:10.1177/1468796807080237

Carlson, E. D. (1985). The impact of international migration upon the timing of marriage and childbearing. Demography, 22(1), 61-72. doi:10.2307/2060986

Castles, S., \& Miller, M. J. (2009). The age of migration: International population movements in the modern world (Vol. Fourth Edi). New York: Guilford Press.

Cebolla-Boado, H., \& González-Ferrer, A. (2008). La inmigración en España 2000-2007. Centro de Estudios Políticos y Constitucionales, Madrid.

Cebolla-Boado, H., \& González-Ferrer, A. (2013). Cómo se ha gestionado la inmigración en España. (A. Editorial, Ed.). Madrid.

Coleman, D. A. (2006). Europe's demographic future: Determinants, dimensions, and challenges. Population and Development Review, 32, 52-95. doi:10.1111/j.17284457.2006.tb00003.x

Cortina Trilla, C., Esteve, A., \& Domingo, A. (2008). Marriage patterns of the foreign-born population in a new country of immigration: The case of Spain. International Migration Review, 42(4), 877-902. doi:10.1111/j.1747-7379.2008.00151.x

Crul, M., \& Vermeulen, H. (2003). The second generation in Europe. International Migration 
Review, 37(4), 965-986. doi:10.2307/30037782

De Valk, H. A. G., \& Díez Medrano, J. (2014). Guest Editorial on Meeting and Mating Across Borders: Union Formation in the European Union Single Market. Population, Space and Place, 20, 103-109. doi:10.1002/psp.1768

Domínguez-Folgueras, M., \& Castro-Martín, T. (2008). Women's changing socioeconomic position and union formation in Spain and Portugal. Demographic Research, 19, 15131549.

Domínguez-Folgueras, M., \& Castro-Martín, T. (2013). Cohabitation in Spain: No longer a marginal path to family formation. Journal of Marriage and Family, 75(2), 422-437. doi:10.1111/jomf.12013

Dribe, M., \& Lundh, C. (2012). Intermarriage, value context and union dissolution: Sweden 1990-2005. European Journal of Population, 28(2), 139-158. doi:10.1007/s10680-0119253-y

Ermisch, J., \& Francesconi, M. (2000). Cohabitation in Great Britain: Not for long, but here to stay. Journal of the Royal Statistical Society. Series A (Statistics in Society), 163(2), 153171. doi:10.2307/2680495

Esping-Andersen, G. (1990). The three worlds of welfare capitalism. Cambridge: Polity.

Fassmann, H. (1997). Is the Austrian labour market ethnically segmented? European Journal of Population, 13(1), 17-32. doi:10.1023/a:1005738004073

Fassmann, H., \& Münz, R. (1994). European migration in the late twentieth century. Historical patterns, actual trends, and social implications. Laxenburg, Austria: International Institute for Applied Systems Analysis.

Fibbi, R., Lerch, M., \& Wanner, P. (2007). Naturalisation and socio-economic characteristics of youth of immigrant descent in Switzerland. Journal of Ethnic and Migration Studies, 33(7), 1121-1144. doi:10.1080/13691830701541655

Frejka, T. (1996). International migration in Central and Eastern Europe and the Commonwealth of Independent States. (T. Frejka, Ed.). Geneva and New York: United Nations.

Goldscheider, F. K., Goldscheider, C., \& Bernhardt, E. M. (2011). Creating egalitarian families among the adult children of Turkish- and Polish-origin immigrants in Sweden. International Migration Review, 45(1), 68-88. doi:10.1111/j.1747-7379.2010.00839.x

González-Ferrer, A. (2006). Who do immigrants marry? Partner choice among single immigrants in Germany. European Sociological Review, 22(2), 171-185. doi:10.1093/esr/jci050

González-Ferrer, A., Cortina Trilla, C., Obućina, O., \& Castro-martín, T. (2018). Mixed marriages between immigrants and natives in Spain: The gendered effect of marriage market constraints. Demographic Research, 39(1), 1-32. doi:10.4054/DemRes.2018.39.1

González-Ferrer, A., Hannemann, T., \& Castro-Martín, T. (2016). Partnership formation and dissolution among immigrants in the Spanish context. Demographic Research, 35(1), 130. doi:10.4054/DemRes.2016.35.1

Hannemann, T., \& Kulu, H. (2015). Union formation and dissolution among immigrants and their descendants in the United Kingdom. Demographic Research, 33(1), 273-312. doi:10.4054/DemRes.2015.33.10

Hannemann, T., Kulu, H., Rahnu, L., Puur, A., Hărăguș, M., Obućina, O., et al. (2018). Coethnic marriage versus intermarriage among immigrants and their descendants: A comparison across seven European countries using event-history analysis. Demographic Research, 39(17), 487-524. doi:10.4054/DemRes.2018.39.17

Hernandez, D. J., Macartney, S., \& Blanchard, V. L. (2009). Children in immigrant families in eight affluent societies: Their family, national, and international context. Florence, Italy: UNICEF Innocenti Research Centre. 
Hervitz, H. M. (1985). Selectivity, adaptation, or disruption? A comparison of alternative hypotheses on the effects of migration on fertility: The case of Brazil. International Migration Review, 19(2), 293-317. doi:10.2307/2545774

Hoem, J. M. (1975). Fertility and out-migration: reflections on research approaches in empirical investigations of the association between two demographic phenomena.

Hoem, J. M., Gabrielli, G., Jasilioniene, A., Kostova, D., \& Matysiak, A. (2010). Levels of recent union formation: Six European countries compared. Demographic Research, 22(9), 199-210. doi:10.4054/DemRes.2010.22.9

Huschek, D., de Valk, H. A. G., \& Liefbroer, A. C. (2012). Partner choice patterns among the descendants of Turkish immigrants in Europe. European Journal of Population, 28(3), 241-268. doi:10.1007/s10680-012-9265-2

Huschek, D., Liefbroer, A. C., \& de Valk, H. a G. (2010). Timing of first union among secondgeneration Turks in Europe: The role of parents, peers and institutional context. Demographic Research, 22, 473-504. doi:10.4054/DemRes.2010.22.16

Jalovaara, M., \& Kulu, H. (2019). Homeownership after separation: A longitudinal analysis of Finnish register data. Demographic Research, 41, 847-872. doi: 10.4054/DemRes.2019.41.29

Kalmijn, M., \& Van Tubergen, F. (2006). Ethnic intermarriage in the Netherlands: Confirmations and refutations of accepted insights. European Journal of Population, 22(4), 371-397. doi:10.1007/s10680-006-9105-3

Katus, K., Puur, A., \& Sakkeus, L. (2008). Family formation in the Baltic countries: A transformation in the legacy of state socialism. Journal of Baltic Studies, 39(2), 123-156. doi:10.1080/01629770802031218

Kleinepier, T., \& de Valk, H. A. G. (2016). Ethnic differences in family trajectories of young adult women in the Netherlands: Timing and sequencing of events. Demographic Research, 35(1), 671-710. doi:10.4054/DemRes.2016.35.24

Kristen, C., Reimer, D., \& Kogan, I. (2008). Higher education entry of Turkish immigrant youth in Germany. International Journal of Comparative Sociology, 49(2-3), 127-151. doi:10.1177/0020715208088909

Kulu, H. (2003). Post-war immigration to Estonia: a comparative perspective. In R. Ohliger, K. Schönwälder, \& T. Triadafilopoulos (Eds.), European encounters, 1945-2000: Migrants, migration and European societies since 1945 (pp. 38-52). Aldershot: Ashgate.

Kulu, H. (2006). Fertility of internal migrants: Comparison between Austria and Poland. Population Space and Place, 12(3), 147-170. doi:10.1002/psp.406

Kulu, H., \& Hannemann, T. (2018). Mixed marriage among immigrants and their descendants in the United Kingdom: Analysis of longitudinal data with missing information. Population Studies, 4728, 1477-4747. doi:10.1080/00324728.2018.1493136

Kulu, H., Hannemann, T., Pailhé, A., Neels, K., Krapf, S., González-Ferrer, A., \& Andersson, G. (2017). Fertility by Birth Order among the Descendants of Immigrants in Selected European Countries. Population and Development Review, 43(1), 31-60. doi:10.1111/padr.12037

Kulu, H., \& Milewski, N. (2007). Family change and migration in the life course: An introduction. Demographic Research, 17, 567-590. doi:10.4054/DemRes.2007.17.19

Lesthaeghe, R., \& Neels, K. (2002). From the first to the second demographic transition : An interpretation of the spatial continuity of demographic innovation in France, Belgium and Switzerland. European Journal of Population, 18(2), 325-360. doi:doi:10.1023/A:1021125800070

Macisco, J. J., Bouvier, L. F., \& Weller, R. H. (1970). Effect of labour force participation on relation between migration status and fertility in San-Juan, Puerto-Rico. Milbank Memorial Fund Quarterly-Health and Society, 48(1), 51-70. doi:10.2307/3349288 
Meurs, D., Pailhé, A., \& Simon, P. (2006). The persistence of intergenerational inequalities linked to immigration: Labour market outcomes for immigrants and their descendants in France. Population, 61(5-6), 763-801.

Milewski, N. (2007). First child of immigrant workers and their descendants in West Germany: Interrelation of events, disruption or adaptation? Demographic Research, 17(29), 859895. doi:10.4054/DemRes.2007.17.29

Milewski, N. (2011). Transition to a first birth among Turkish second-generation migrants in Western Europe. Advances in Life Course Research, 16(4), 178-189. doi:10.1016/j.alcr.2011.09.002

Milewski, N., \& Kulu, H. (2014). Mixed marriages in Germany: A high risk of divorce for immigrant-native couples. European Journal of Population, 30(1), 89-113. doi:10.1007/s10680-013-9298-1

Miner, D. C. (2003). Jamaican families. Holistic Nursing Practice, 17(1), 27-35.

Murphy, M. (2000). The evolution of cohabitation in Britain, 1960-95. Population Studies, 54(1), 43-56. doi:10.2307/2584632

Pailhé, A. (2015). Partnership dynamics across generations of immigration in France: Structural vs. Cultural factors. Demographic Research, 33(1), 451-498. doi:10.4054/DemRes.2015.33.16

Peach, C. (1998). South Asian and Caribbean ethnic minority housing choice in Britain. Urban Studies, 35(10), 1657-1680. doi:10.1080/0042098984097

Perelli-Harris, B., \& Gassen, N. S. (2012). How similar are cohabitation and marriage? Legal approaches to cohabitation across Western Europe. Population and Development Review, 38(3), 435-467. doi:10.1111/j.1728-4457.2012.00511.x

Perelli-Harris, B., \& Gerber, T. P. (2011). Nonmarital childbearing in Russia: Second demographic transition or pattern of disadvantage? Demography, 48(1), 317-342. doi:10.1007/s13524-010-0001-4

Perelli-Harris, B., \& Lyons-Amos, M. (2016). Partnership Patterns in the United States and across Europe: The Role of Education and Country Context. Social Foces, 95(1), 251282. doi:doi.org/10.1093/sf/sow054

Perelli-Harris, B., Sigle-Rushton, W., Kreyenfeld, M., Lappegård, T., Keizer, R., \& Berghammer, C. (2010). The educational gradient of childbearing within cohabitation in Europe. Population and Development Review, 36(4), 775-801. doi:10.1111/j.17284457.2010.00357.x

Preston, D. L. (2005). Poisson regression in epidemiology. In P. Armitage \& T. Colton (Eds.), Encyclopedia of biostatistics (Vol. 6, pp. 4124-4127). New York: Wiley.

Puur, A., Rahnu, L., Abuladze, L., Sakkeus, L., \& Zakharov, S. (2017). Childbearing among first- and second- generation Russians in Estonia against the background of the sending and host countries. Demographic Research, 36(41), 1209-1254. doi:10.4054/DemRes.2017.36.41

Puur, A., Rahnu, L., Maslauskaite, A., Stankuniene, V., \& Zakharov, S. (2012). Transformation of partnership formation in Eastern Europe: The legacy of the past demographic divide. Journal of Comparative Family Studies, 43(3), 389-418.

Puur, A., Rahnu, L., Sakkeus, L., Klesment, M., \& Abuladze, L. (2018). The formation of ethnically mixed partnerships in estonia: A stalling trend from a two-sides perspective. Demographic Research, 38(38), 1111-1154. doi:10.4054/DemRes.2018.38.38

Rahnu, L., Puur, A., Sakkeus, L., \& Klesment, M. (2015). Partnership dynamics among migrants and their descendants in Estonia. Demographic Research, 32(56), 1519-1566. http://www.demographic-research.org/volumes/vol32/56/

Reher, D. S. (1998). Family ties in Western Europe: Persistent contrasts. Population and Development Review, 24(2), 203-234. 
Salt, J., \& Clout, H. (1976). Migration in post-war Europe: Geographical essays. London : Oxford University Press.

Seifert, W. (1997). Admission policy, patterns of migration and integration: The German and French case compared. New community, 23(4), 441-460. doi:10.1080/1369183X.1997.9976605

Serow, W. J., Nam, C. B., Sly, D. F., \& Weller, R. H. (1990). Handbook on international migration. New York: Greenwood Press.

Sigle-Rushton, W. (2008). England and Wales: Stable fertility and pronounced social status differences. Demographic Research, 19(15), 455-502. doi:10.4054/DemRes.2008.19.15

Sobotka, T. (2008). The rising importance of migrants for childbearing in Europe. Demographic Research, S7(9), 225-248. http://www.demographicresearch.org/special/7/9/

Sobotka, T., \& Toulemon, L. (2008). Changing family and partnership behaviour: Common trends and persistent diversity across Europe. Demographic Research, S7(6), 85-138. http://www.demographic-research.org/special/7/6/

Toulemon, L. (2004). Fertility among immigrant women: New data, new approach. Population and Societies, 400, 1-4.

University of Essex, Institute for Social and Economic Research, \& NatCen Social Research. (2014). Understanding Society: Waves 1-4, 2009-2013. UK Data Service. doi:http://dx.doi.org/10.5255/UKDA-SN-6614-6

Van Niekerk, M. (2007). Second-generation Caribbeans in the Netherlands: Different migration histories, diverging trajectories. Journal of Ethnic and Migration Studies, 33(7), 10631081. doi:10.1080/13691830701541580

Zorlu, A., \& Mulder, C. H. (2011). Ethnic Differences in Leaving Home: Timing and Pathways. Demography, 48(1), 49-72. doi:10.1007/s13524-010-0012-1 
Table 1: Number of events and person-months by union transition and migrant group

\begin{tabular}{|c|c|c|c|c|c|c|c|c|c|c|c|c|c|}
\hline \multirow{3}{*}{ Country } & \multirow{3}{*}{ Migrant group } & \multicolumn{4}{|c|}{ First union (1) or (2) } & \multirow{2}{*}{\multicolumn{2}{|c|}{$\begin{array}{r}\text { Cohabitation (1) } \\
\text { Events }\end{array}$}} & \multirow{2}{*}{\multicolumn{2}{|c|}{$\begin{array}{r}\text { Direct marriage (2) } \\
\text { Events }\end{array}$}} & \multicolumn{4}{|c|}{ Divorce (3) } \\
\hline & & \multicolumn{2}{|c|}{ Person-months } & \multicolumn{2}{|c|}{ Events } & & & & & \multicolumn{2}{|c|}{ Person-months } & \multicolumn{2}{|c|}{ Events } \\
\hline & & $\mathrm{N}$ & $\%$ & $\mathrm{~N}$ & $\%$ & \multicolumn{2}{|r|}{$\%$} & \multicolumn{2}{|l|}{$\mathrm{N}$} & $\mathrm{N}$ & $\%$ & $\mathrm{~N}$ & $\%$ \\
\hline \multicolumn{14}{|l|}{ United } \\
\hline \multirow[t]{9}{*}{ Kingdom } & Native & 1073566 & 29.2 & 10800 & 34.7 & 6917 & 40.1 & 3883 & 28.0 & 1157753 & 32.7 & 2267 & 43.2 \\
\hline & Europe \& West (1G) & 65860 & 1.8 & 557 & 1.8 & 401 & 2.3 & 156 & 1.1 & 45500 & 1.3 & 76 & 1.4 \\
\hline & Europe \& West (2G) & 76610 & 2.1 & 663 & 2.1 & 445 & 2.6 & 218 & 1.6 & 64398 & 1.8 & 123 & 2.3 \\
\hline & South Asia (1G) & 90699 & 2.5 & 1003 & 3.2 & 34 & 0.2 & 969 & 7.0 & 154764 & 4.4 & 87 & 1.7 \\
\hline & South Asia (2G) & 63493 & 1.7 & 460 & 1.5 & 75 & 0.4 & 385 & 2.8 & 52975 & 1.5 & 75 & 1.4 \\
\hline & Caribbean (1G) & 20931 & 0.6 & 119 & 0.4 & 85 & 0.5 & 34 & 0.2 & 10893 & 0.3 & 27 & 0.5 \\
\hline & Caribbean (2G) & 47406 & 1.3 & 292 & 0.9 & 233 & 1.4 & 59 & 0.4 & 21650 & 0.6 & 64 & 1.2 \\
\hline & Other (1G) & 243611 & 6.6 & 1667 & 5.4 & 721 & 4.2 & 946 & 6.8 & 180599 & 5.1 & 276 & 5.3 \\
\hline & Other (2G) & 69002 & 1.9 & 457 & 1.5 & 327 & 1.9 & 130 & 0.9 & 31977 & 0.9 & 71 & 1.4 \\
\hline \multirow[t]{3}{*}{ Estonia } & Native & 283786 & 7.7 & 3734 & 12.0 & 2948 & 17.1 & 786 & 5.7 & 308492 & 8.7 & 662 & 12.6 \\
\hline & Russian speaking (1G) & 63484 & 1.7 & 951 & 3.1 & 445 & 2.6 & 506 & 3.6 & 113029 & 3.2 & 252 & 4.8 \\
\hline & Russian speaking (2G) & 53254 & 1.4 & 699 & 2.2 & 369 & 2.1 & 330 & 2.4 & 66841 & 1.9 & 173 & 3.3 \\
\hline \multirow[t]{9}{*}{ France } & Native & 165792 & 4.5 & 1534 & 4.9 & 1160 & 6.7 & 374 & 2.7 & 151107 & 4.3 & 216 & 4.1 \\
\hline & Maghreb (1G) & 100455 & 2.7 & 873 & 2.8 & 189 & 1.1 & 684 & 4.9 & 122212 & 3.4 & 154 & 2.9 \\
\hline & Maghreb (2G) & 121111 & 3.3 & 789 & 2.5 & 366 & 2.1 & 423 & 3.0 & 55214 & 1.6 & 122 & 2.3 \\
\hline & Sub-Saharan Africa (1G) & 77220 & 2.1 & 550 & 1.8 & 289 & 1.7 & 261 & 1.9 & 53268 & 1.5 & 102 & 1.9 \\
\hline & Sub-Saharan Africa (2G) & 33450 & 0.9 & 150 & 0.5 & 103 & 0.6 & 47 & 0.3 & 4697 & 0.1 & 19 & 0.4 \\
\hline & Turkey (1G) & 22060 & 0.6 & 308 & 1.0 & 48 & 0.3 & 260 & 1.9 & 48175 & 1.4 & 21 & 0.4 \\
\hline & Turkey (2G) & 14275 & 0.4 & 114 & 0.4 & 20 & 0.1 & 94 & 0.7 & 6331 & 0.2 & 13 & 0.2 \\
\hline & South Europe (1G) & 51554 & 1.4 & 574 & 1.8 & 252 & 1.5 & 322 & 2.3 & 95860 & 2.7 & 91 & 1.7 \\
\hline & South Europe (2G) & 119291 & 3.2 & 992 & 3.2 & 746 & 4.3 & 246 & 1.8 & 82493 & 2.3 & 122 & 2.3 \\
\hline \multirow[t]{5}{*}{ Spain } & Native & 757041 & 20.6 & 3460 & 11.1 & 896 & 5.2 & 2564 & 18.5 & 656851 & 18.5 & 189 & 3.6 \\
\hline & East Europe (1G) & 8744 & 0.2 & 72 & 0.2 & 41 & 0.2 & 31 & 0.2 & 11546 & 0.3 & 4 & 0.1 \\
\hline & Latin America (1G) & 35177 & 1.0 & 210 & 0.7 & 101 & 0.6 & 109 & 0.8 & 29345 & 0.8 & 29 & 0.6 \\
\hline & EU 15 (1G) & 10555 & 0.3 & 63 & 0.2 & 28 & 0.2 & 35 & 0.3 & 9734 & 0.3 & 10 & 0.2 \\
\hline & Other (1G) & 8123 & 0.2 & 43 & 0.1 & 12 & 0.1 & 31 & 0.2 & 7689 & 0.2 & 5 & 0.1 \\
\hline Total & & 3676551 & 100 & 31134 & 100 & 17251 & 100 & 13883 & 100 & 3543391 & 100 & 5250 & 100 \\
\hline
\end{tabular}

Source: Data is from Understanding Society (University of Essex, 2015) 
Table 2: Relative risk of union formation, cohabitation and direct marriage

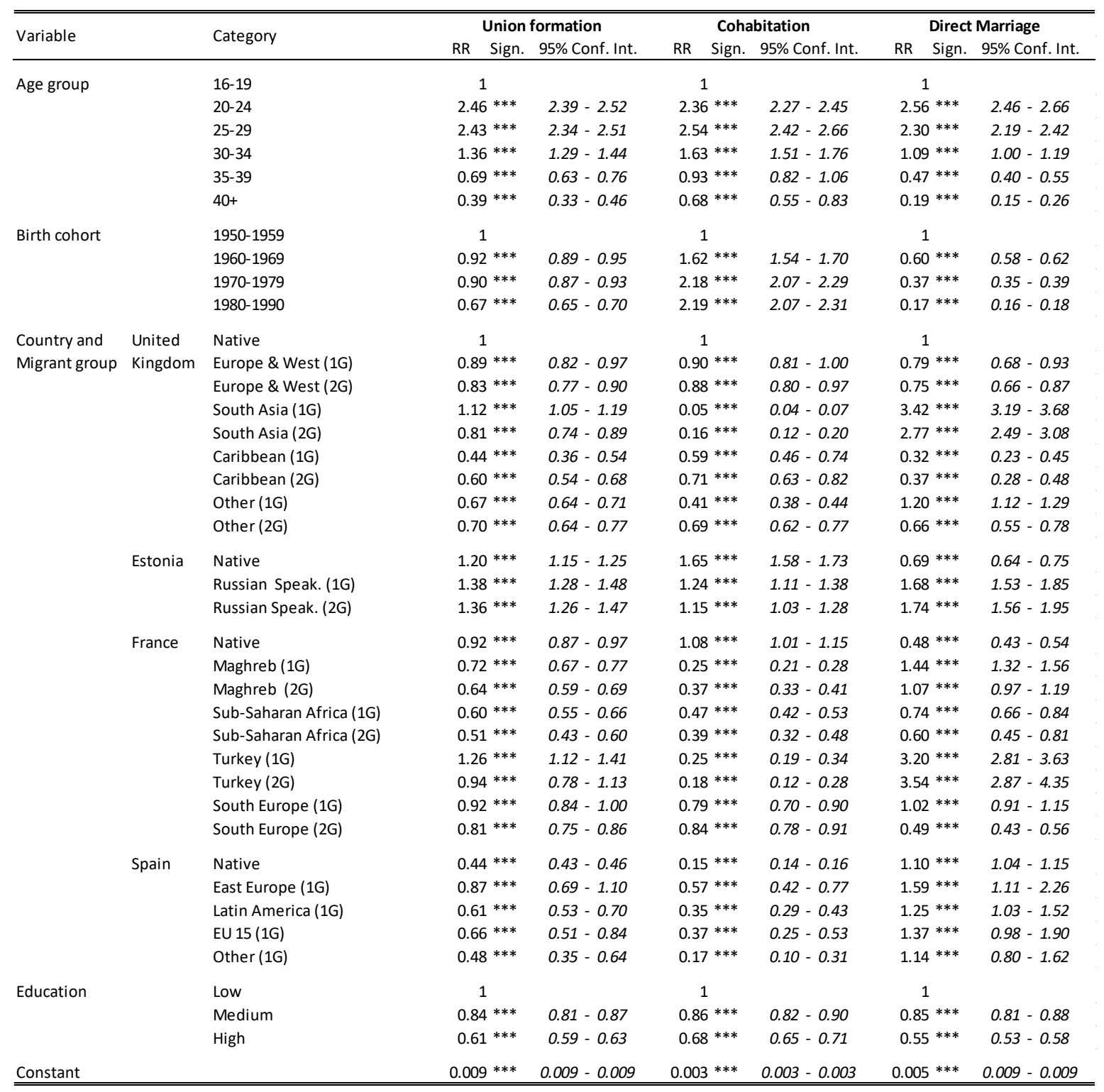

Significance: *** $p<0.01 ;{ }^{* *} p<0.05 ;{ }^{*} p<0.1$

Source: Data is from Understanding Society (University of Essex, 2015)

Note: Individuals are at risk since age 16 and censored at age 45 or last interview date and additionally at date of direct marriage for the cohabitation model and date of cohabitation for the direct marriage model 
Table 3: Relative risks of divorce for all married individuals

\begin{tabular}{|c|c|c|c|c|}
\hline \multirow{2}{*}{\multicolumn{2}{|c|}{ Variable }} & \multirow{2}{*}{ Category } & \multicolumn{2}{|c|}{ Divorce } \\
\hline & & & RR Sign. & 95\% Conf. Int. \\
\hline \multirow{5}{*}{\multicolumn{2}{|c|}{$\begin{array}{l}\text { Union duration in } \\
\text { months }\end{array}$}} & $0-11$ & 1 & \\
\hline & & $12-35$ & $1.75 * * *$ & $1.52-2.02$ \\
\hline & & $36-71$ & $2.19 * * *$ & $1.91-2.52$ \\
\hline & & $72-119$ & $1.95 * * *$ & $1.69-2.23$ \\
\hline & & $120+$ & $1.76^{* * *}$ & $1.54-2.02$ \\
\hline \multirow{4}{*}{\multicolumn{2}{|c|}{ Birth cohort }} & 1950-1959 & 1 & \\
\hline & & 1960-1969 & $1.40 * * *$ & $1.32-1.49$ \\
\hline & & 1970-1979 & $1.45^{* * *}$ & $1.34-1.58$ \\
\hline & & 1980-1989 & $1.86 * * *$ & $1.59-2.19$ \\
\hline Country and & United & Native & 1 & \\
\hline \multirow{25}{*}{ Migrant group } & Kingdom & Europe \& West (1G) & $0.85 * * *$ & $0.67-1.07$ \\
\hline & & Europe \& West (2G) & $1.03 * * *$ & $0.86-1.24$ \\
\hline & & South Asia (1G) & $0.24 * * *$ & $0.20-0.30$ \\
\hline & & South Asia (2G) & $0.60 * * *$ & $0.47-0.75$ \\
\hline & & Caribbean (1G) & $1.36 * * *$ & $0.93-1.99$ \\
\hline & & Caribbean (2G) & $1.48 * * *$ & $1.16-1.90$ \\
\hline & & Other (1G) & $0.74 * * *$ & $0.65-0.84$ \\
\hline & & Other (2G) & $1.14 * * *$ & $0.90-1.44$ \\
\hline & Estonia & Native & $1.26 * * *$ & $1.15-1.37$ \\
\hline & & Russian Speak. (1G) & $1.39 * * *$ & $1.22-1.59$ \\
\hline & & Russian Speak. (2G) & $1.47^{* * *}$ & $1.26-1.72$ \\
\hline & France & Native & $0.69 * * *$ & $0.60-0.80$ \\
\hline & & Maghreb (1G) & $0.58 * * *$ & $0.49-0.68$ \\
\hline & & Maghreb (2G) & $0.92 * * *$ & $0.76-1.11$ \\
\hline & & Sub-Saharan Africa (1G) & $0.82 * * *$ & $0.67-1.01$ \\
\hline & & Sub-Saharan Africa (2G) & $1.68 * * *$ & $1.06-2.65$ \\
\hline & & Turkey (1G) & $0.18^{* * *}$ & $0.11-0.27$ \\
\hline & & Turkey (2G) & $0.73 * * *$ & $0.42-1.27$ \\
\hline & & South Europe (1G) & $0.45 * * *$ & $0.36-0.56$ \\
\hline & & South Europe (2G) & $0.65 * * *$ & $0.54-0.78$ \\
\hline & Spain & Native & $0.13 * * *$ & $0.12-0.16$ \\
\hline & & East Europe (1G) & $0.15 * * *$ & $0.06-0.40$ \\
\hline & & Latin America (1G) & $0.41 * * *$ & $0.28-0.59$ \\
\hline & & EU 15 (1G) & $0.45^{* * *}$ & $0.24-0.83$ \\
\hline & & Other (1G) & $0.28 * * *$ & $0.12-0.68$ \\
\hline \multirow[t]{3}{*}{ Education } & & Low & 1 & \\
\hline & & Medium & $0.94^{* * *}$ & $0.87-1.01$ \\
\hline & & High & $0.71 * * *$ & $0.66-0.77$ \\
\hline Constant & & & $0.001 * * *$ & $0.001-0.001$ \\
\hline
\end{tabular}

Significance: ${ }^{* * *} p<0.01 ;{ }^{* *} p<0.05 ;{ }^{*} p<0.1$

Source: Data is from Understanding Society (University of Essex, 2015)

Note: Individuals are at risk since union start and censored after 20 years in union/marriage or death of partner 
Table 4: Relative risks of cohabitation, marriage and divorce, interaction with birth cohort

\begin{tabular}{|c|c|c|c|c|c|c|c|c|c|c|c|}
\hline \multirow{2}{*}{ Variable } & & \multirow{2}{*}{ Category } & \multicolumn{3}{|c|}{ Cohabitation } & \multicolumn{3}{|c|}{ Marriage } & \multicolumn{3}{|c|}{ Divorce } \\
\hline & & & RR Sign. & $\mathrm{RR}$ & Sign. & RR Sign. & $\mathrm{RR}$ & Sign. & RR Sign. & $\mathrm{RR}$ & Sign. \\
\hline \multirow{3}{*}{\multicolumn{2}{|c|}{ Age group }} & $20-24$ & $2.36 * * *$ & & & $2.60 * * *$ & & & & & \\
\hline & & $25-29$ & $2.56 * * *$ & & & $2.41 * * *$ & & & & & \\
\hline & & $30-34$ & $1.65 * * *$ & & & $1.17 * * *$ & & & & & \\
\hline \multirow{4}{*}{$\begin{array}{l}\text { Union duration } \\
\text { In months }\end{array}$} & & $0-11$ & & & & & & & 1 & & \\
\hline & & $12-35$ & & & & & & & $1.75 * * *$ & & \\
\hline & & $36-71$ & & & & & & & $2.17^{* * *}$ & & \\
\hline & & $72-119$ & & & & & & & $1.91 * * *$ & & \\
\hline Country and & United & Native & 1 & 1.99 & $9^{* * *}$ & 1 & 0.17 & $7^{* * *}$ & 1 & 1.39 & $* * *$ \\
\hline \multirow[t]{16}{*}{ Migrant group } & Kingdom & Europe \& West (1G) & 1.03 & 1.62 & $2 * * *$ & $0.66 * * *$ & 0.29 & $9 * * *$ & 0.95 & 0.97 & \\
\hline & & South Asia (1G) & $0.05 * * *$ & 0.09 & $9 * * *$ & $1.79 * * *$ & 1.87 & $7 * * *$ & $0.17^{* * *}$ & 0.42 & $* * *$ \\
\hline & & Caribbean (1G) & $0.60 * * *$ & 1.08 & & $0.29 * * *$ & 0.18 & $8 * * *$ & 1.14 & 2.88 & $* *$ \\
\hline & & Other (1G) & $0.43 * * *$ & 0.78 & $8 * * *$ & $0.78 * * *$ & 0.60 & $0 * * *$ & $0.80 * * *$ & 0.95 & \\
\hline & & Europe \& West (2G) & 0.96 & 1.65 & $5 * * *$ & $0.74 * * *$ & 0.14 & $4 * * *$ & 1.01 & 1.43 & \\
\hline & & South Asia (2G) & $0.50 * * *$ & 0.20 & $0 * * *$ & $1.23 *$ & 1.06 & & $0.67^{* *}$ & 0.82 & \\
\hline & & Caribbean (2G) & 1.03 & 1.11 & & $0.30^{* * *}$ & 0.11 & $1 * * *$ & $1.46^{* *}$ & 2.56 & $* * *$ \\
\hline & & Other (2G) & 1.10 & 1.03 & & $0.37 * * *$ & 0.34 & $4 * * *$ & $1.56 * * *$ & 0.66 & \\
\hline & Estonia & Native & $1.89 * * *$ & 2.71 & $1 * * *$ & $0.68 * * *$ & 0.18 & $8 * * *$ & $1.24 * * *$ & 1.63 & $* * *$ \\
\hline & & South Europe (1G) & 0.92 & 1.27 & $7^{*}$ & $0.90 *$ & 0.33 & $3 * * *$ & $0.49 * * *$ & 0.21 & $* * *$ \\
\hline & & Maghreb \& Turkey (2G) & $0.75 * * *$ & 0.55 & $5 * * *$ & $0.35 * * *$ & 0.57 & $7 * * *$ & 1.14 & 1.15 & \\
\hline & & Sub-Saharan Africa (2G) & 0.88 & 0.68 & $8 * * *$ & $0.09 * * *$ & 0.21 & $1 * * *$ & $2.77^{*}$ & 2.18 & $* * *$ \\
\hline & & South Europe (2G) & $1.12 *$ & 1.51 & $1 * * *$ & $0.41 * * *$ & 0.14 & $4^{* * *}$ & $0.82 *$ & 0.66 & $* *$ \\
\hline & Spain & Native & $0.22 * * *$ & 0.24 & $4 * * *$ & $1.09 * * *$ & 0.23 & $3 * * *$ & $0.16 * * *$ & 0.12 & $* * *$ \\
\hline & & East EU \& EU15 (1G) & $0.57 *$ & 0.84 & & 1.30 & 0.37 & $7 * * *$ & $0.44 * *$ & 0.27 & $* * *$ \\
\hline & & Latin Am. \& others (1G) & $0.50 * * *$ & 0.54 & $4^{* * *}$ & 0.97 & 0.36 & $6 * * *$ & $0.61 * *$ & 0.37 & $* * *$ \\
\hline \multirow{3}{*}{ Education } & & Low & 1 & & & 1 & & & 1 & & \\
\hline & & Medium & $0.87 * * *$ & & & $0.80 * * *$ & & & 0.98 & & \\
\hline & & High & $0.70^{* * *}$ & & & $0.52 * * *$ & & & $0.74 * * *$ & & \\
\hline Constant & & & $0.003 * * *$ & & & $0.006 * * *$ & & & $0.001 * * *$ & & \\
\hline
\end{tabular}

Significance: ${ }^{* * *} p<0.01 ; * * p<0.05 ; * p<0.1$

Source: Data is from Understanding Society (University of Essex, 2015)

Note: Model specifications for cohabitation and marriage see Table 3, for divorce see Table 4 
Figure 1: Relative risks of formation of direct marriage (Mar) and cohabitation (Coh) by birth cohort, simultaneous analysis, only natives of the respective countries

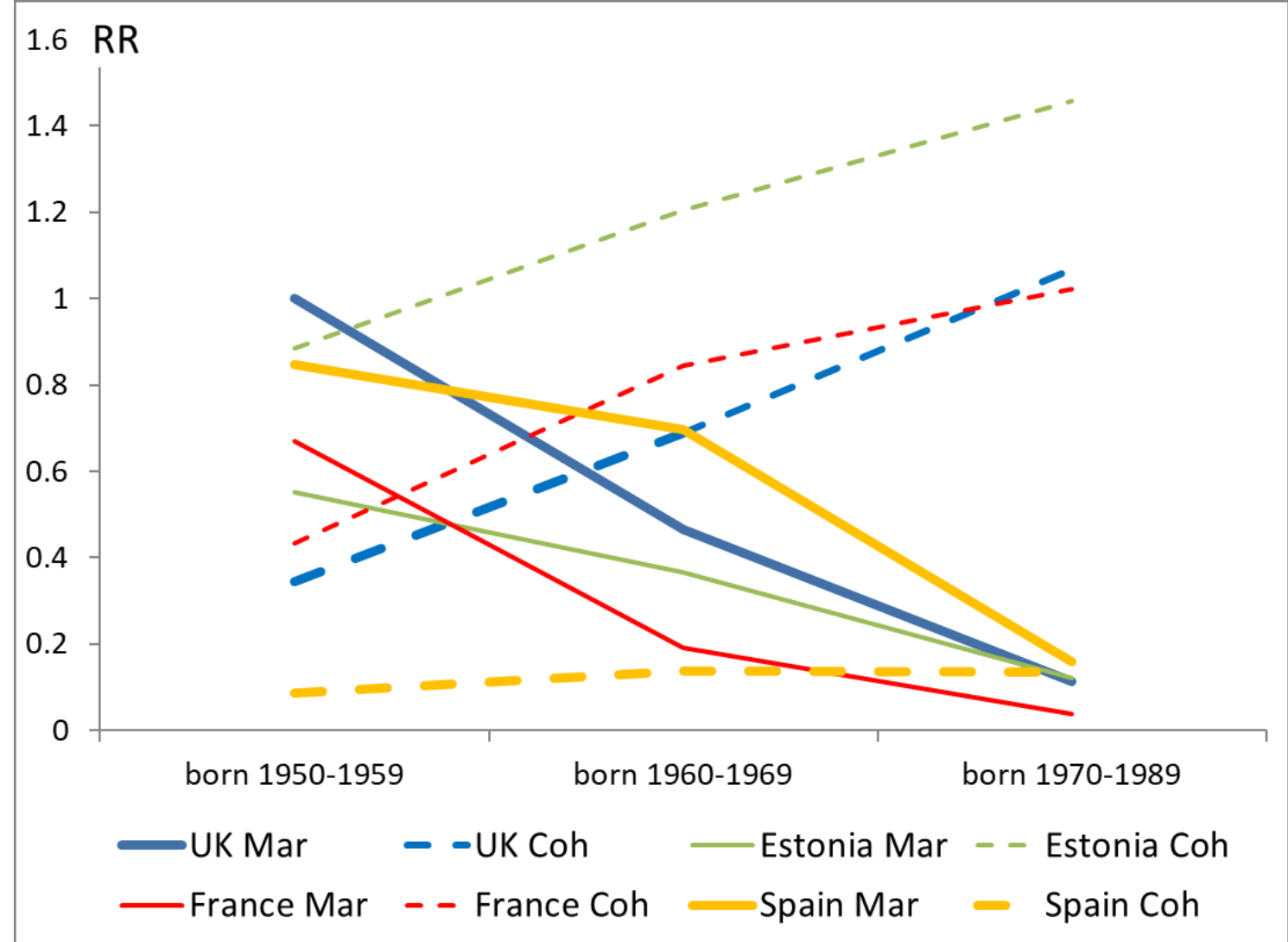

Source: Data is from Understanding Society (University of Essex, 2015) Note: Controlled for age and educational level

Individuals are at risk since age 16 and censored at age 45, last interview date or direct marriage for the event of cohabitation and at date of cohabitation for the event of direct marriage

Figure 2: Partnership transitions analysed in this study

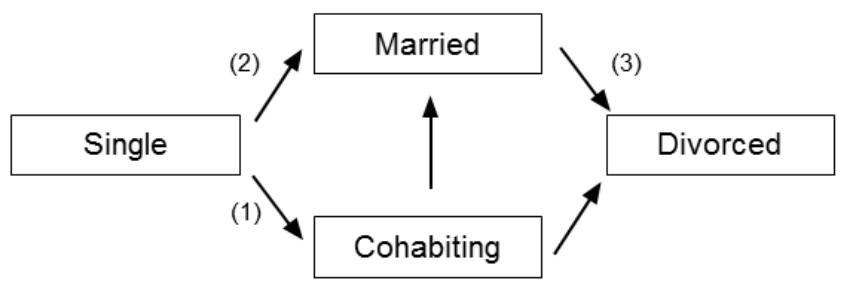

(1) or (2) First union formation

(1) Cohabitation

(2) Direct marriage

(3) Divorce from marriage 
Figure 3: Relative risks of formation of first cohabitation

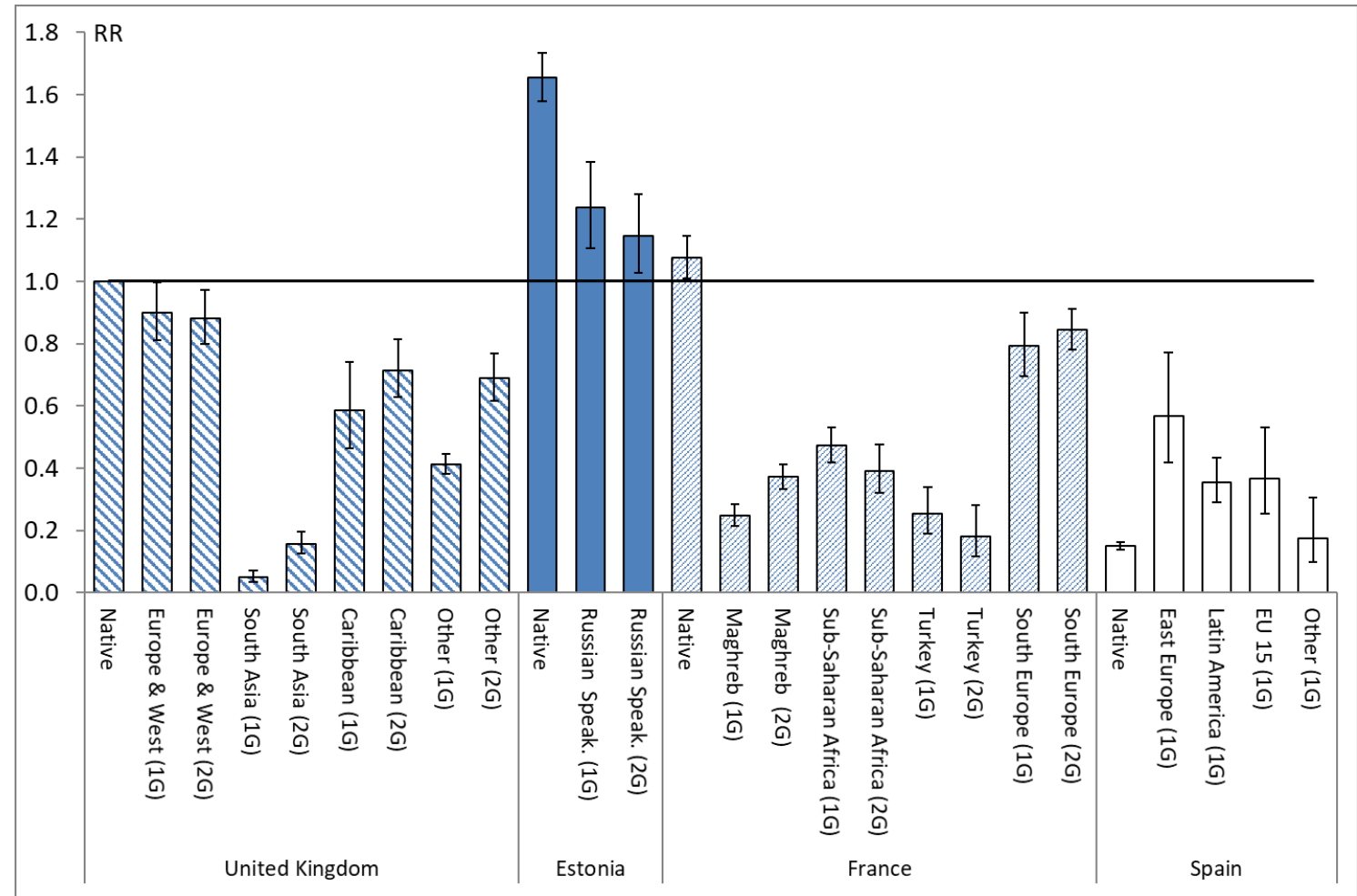

Source: Data is from Understanding Society (University of Essex, 2015)

Note: Controlled for age, cohort and educational level

$1 \mathrm{G}$ refers to immigrants of the first generation and $2 \mathrm{G}$ refers to descendants of immigrants respectively

Figure 4: Relative risks of formation of direct marriage

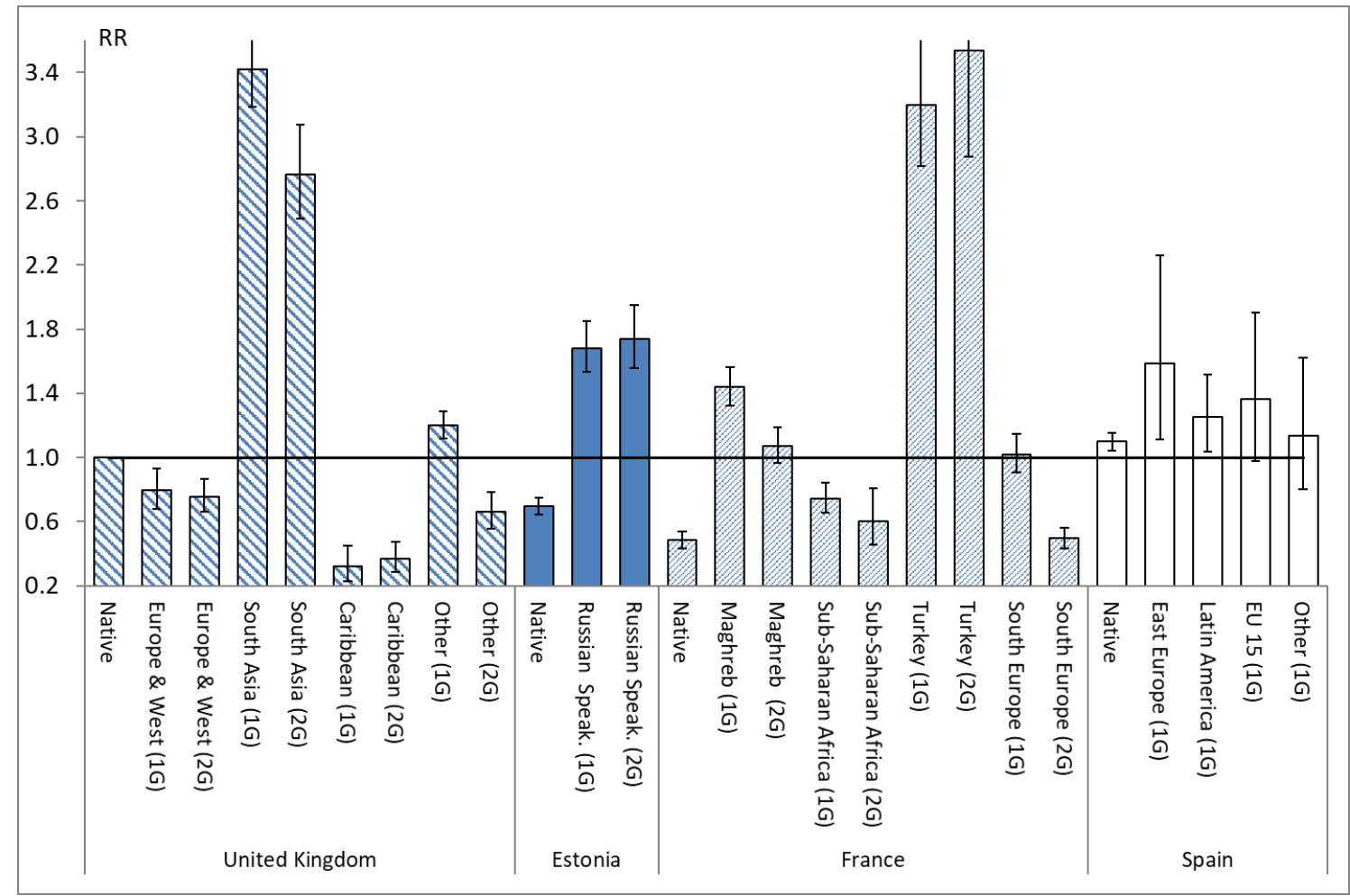

Source: Data is from Understanding Society (University of Essex, 2015)

Note: Controlled for age, cohort and educational level 
Figure 5: Relative risks of divorce from first marriage

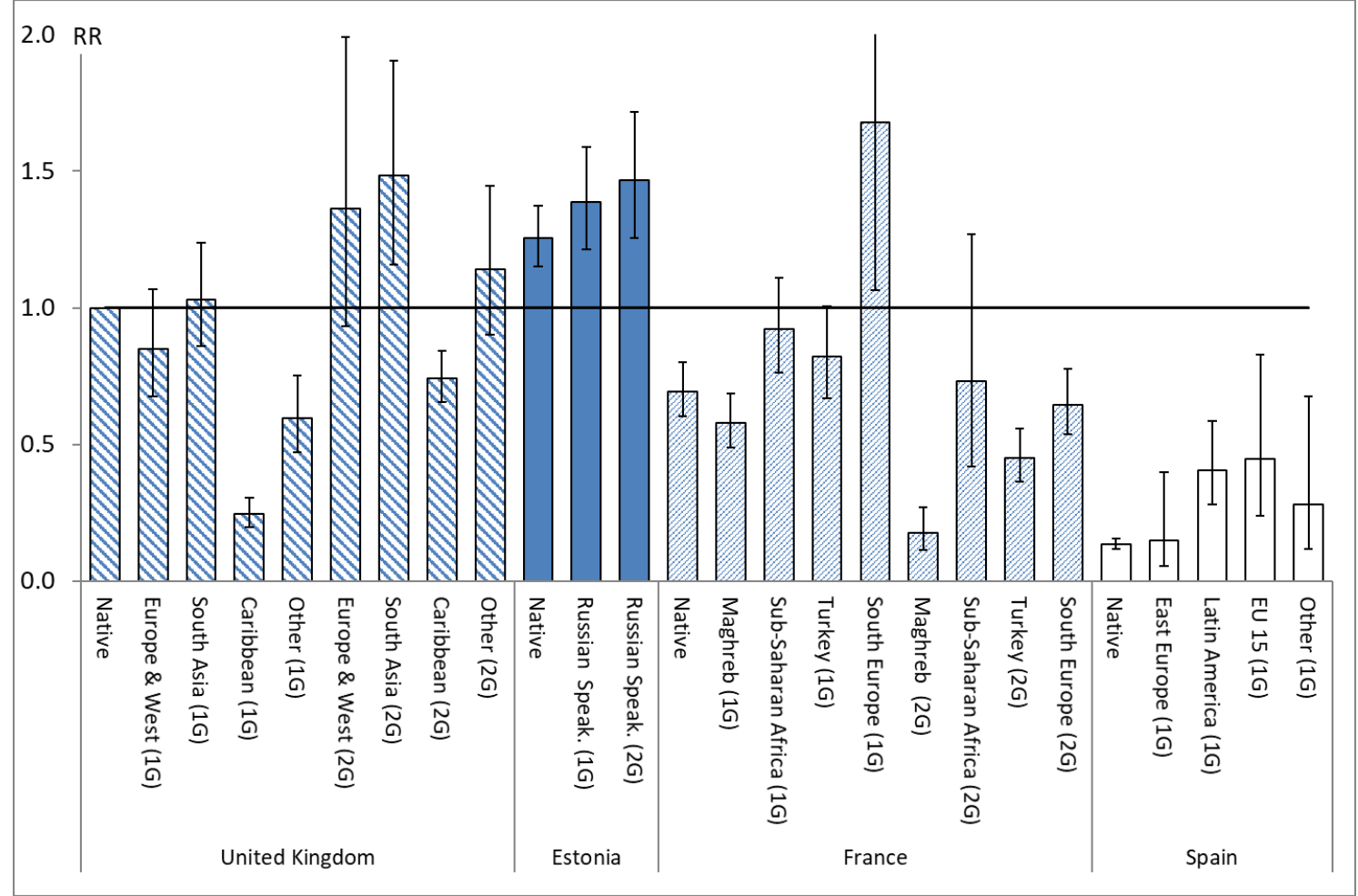

Source: Data is from Understanding Society (University of Essex, 2015)

Note: Controlled for marriage duration baseline, cohort groups and education level

$1 \mathrm{G}$ refers to immigrants of the first generation and $2 \mathrm{G}$ refers to descendants of immigrants respectively 